\title{
Mycoplasma cricetuli, a New Species from the Conjunctivas of Chinese Hamsters
}

\author{
AURIOL C. HILL \\ Medical Research Council Laboratory Animals Centre, Carshalton, Surrey SM5 4EF, England
}

\begin{abstract}
Mycoplasmas were isolated from the conjunctivas and nasopharynges of Chinese hamsters. Four clones obtained from three separate colonies were examined in detail. These clones were indistinguishable from each other and were serologically distinct from 67 recognized Mycoplasma spp. Strain CH (NCTC 10190 ) is designated the type strain of a new species, $M$. cricetuli. This is the only Mycoplasma species recorded from Chinese hamsters.
\end{abstract}

The isolation of mycoplasmas from Chinese hamsters (Cricetulus griseus) was reported by Hill (10). Fifty-five animals were examined from one colony; mycoplasmas were isolated from the conjunctivas of all 55 and the nasopharynges of 47 , and a few organisms were isolated from the lungs of 3 . No other reports have been published on mycoplasma infection in Chinese hamsters.

This paper presents the characterization of four clones of mycoplasmas from Chinese hamsters and proposes their classification as a new Mycoplasma species.

\section{MATERIALS AND METHODS}

Mycoplasma strains. Mycoplasma strains $\mathrm{CH}$ and $\mathrm{SH}$ were isolated by the author from the conjunctivas of Chinese hamsters in two separate animal colonies in the United Kingdom. Strain HO was recovered by A. Polak-Vogelzang from Chinese hamsters in the Netherlands, and strain LE was recovered from the conjunctiva of a lemming (Lagurus lagurus) housed in the room next to the Chinese hamsters infected with strain CH.

Strain $\mathrm{CH}$ was also recovered from the nasopharynges and brains of some animals. There was no evidence of pathogenicity associated with these mycoplasma infections.

Mycoplasma species. $\bar{M}$ ycoplasma type cultures were obtained from the National Collection of Type Cultures, Collindale, England, and from M. F. Barile, R. J. Fallon, J. T. Heywood, F. T. W. Jordan, D. E. Jasper, H. Kirchoff, R. H. Leach, G. Smith, D. Taylor-Robinson, and J. G. Tully.

Medium and growth conditions. The basic culture medium was described by Taylor-Robinson et al. (23) and Hill (9). The purified agar used in the growth medium was either lonagar no. 2 (Oxoid Ltd., Basingstoke, England) or Lab M agar (Lab M, London, England). Depending upon their biochemical activity, mycoplasmas were grown in basic liquid medium containing $1 \%$ glucose $(\mathrm{pH} 7.8)$ or $1 \%$ arginine $(\mathrm{pH}$ 7.3). Agar cultures were incubated at $35^{\circ} \mathrm{C}$ either in a humid chamber or under anaerobic conditions. Liquid cultures were stored at $-70^{\circ} \mathrm{C}$ in ampoules.

Growth requirements and characteristics. The Chinese hamster mycoplasma isolates were cloned three times to produce pure cultures. The strains were subcultured onto solid medium and grown for 1 week under both aerobic and anaerobic conditions. Their ability to grow and to produce a pearly layer was recorded. Inhibition of growth by methylene blue was investigated by adding $0.002 \%$ methylene blue to the basic solid medium. The production of a film was shown by inoculating mycoplasmas onto basic medium enriched with $10 \%$ egg yolk emulsion (6). Plates were examined at 3,7 , and 14 days.

Absence of reversion. Isolates were subcultured by several passages onto both solid and liquid media which contained no microbial inhibitors and incubated aerobically to see whether the organism reverted to a bacterial form. Isolates were also treated with Diene stain (24).

Morphological studies. Mycoplasma colonies grown on agar were examined after 2, 7, and 14 days of incubation. Colonies were transferred to slides and stained with Giemsa stain $(7,12)$. Liquid cultures were observed by dark-field microscopy, and organisms were stained with Giemsa stain (12). They were also examined by electron microscopy.

Filtration studies. Cultures (24-h incubation) were diluted 1:10 in liquid medium and then filtered through a series of Millipore membrane filters (Millipore Corp., Bedford, Mass.) with pore diameters of 220 , $300,450,650$, and $800 \mathrm{~nm}$. The number of colonyforming units per milliliter was determined and compared with the original 1:10 culture dilution.

Sterol dependence. The mycoplasmas were seeded onto a serum-free medium supplemented with bovine serum albumin, glucose, and palmitic acid. Cholesterol, dissolved in Tween 80 , was added to give concentrations of $20,10,5$, and $1 \mu \mathrm{g} / \mathrm{ml}$. Plates containing no cholesterol were included $(4,5,20,26)$. Mycoplasmas were also subcultured onto medium without serum.

Isolates were tested for susceptibility with disks containing $0.02 \mathrm{ml}$ of either $1.5 \%$ ethanolic solution of digitonin (Sigma Chemical Company, St. Louis, Mo.) or $20 \%$ aqueous solution of sodium polyanetholsulfonate (Koch-Light Laboratories Ltd., Colnbrook, En- 
TABLE 1. Mycoplasma type species and animal origin

\begin{tabular}{|c|c|c|c|c|c|}
\hline Mycoplasma sp. & Type strain & $\begin{array}{c}\text { Species or } \\
\text { place of origin }\end{array}$ & Mycoplasma sp. & Type strain & $\begin{array}{c}\text { Species or } \\
\text { place of origin }\end{array}$ \\
\hline M. agalactiae & PG2 & Sheep & M. gateae & $\mathrm{CS}$ & Cat \\
\hline M. alkalescens & PG51 & Cattle & A. granularum & BTS39 & Pig \\
\hline M. alvi & Ilsley & Cattle & A. hippikon & CI & Horse \\
\hline M. anatis & 1340 & Duck & $M$. hominis & PG21 & Human \\
\hline$M$. arginini & $\mathrm{G} 230$ & $\begin{array}{r}\text { Cell cultures, } \\
\text { sheep, goat }\end{array}$ & $\begin{array}{l}M . \text { hyorhinis } \\
M . \text { hyosynoviae }\end{array}$ & $\begin{array}{l}7 \\
\text { S16 }\end{array}$ & $\begin{array}{l}\text { Pig } \\
\text { Pig }\end{array}$ \\
\hline M. arthritidis & PG6 & Rat & $M$. iners & PG30 & Chicken \\
\hline $\begin{array}{l}\text { Acholeplasma } \\
\text { axanthum }\end{array}$ & S743 & $\begin{array}{l}\text { Murine tissue } \\
\text { culture cell } \\
\text { line }\end{array}$ & $\begin{array}{l}\text { M. iowae } \\
\text { A. laidlawii } \\
M . \text { lipophilum }\end{array}$ & $\begin{array}{l}1695 \\
\text { PG8 } \\
\text { MaBV }\end{array}$ & $\begin{array}{l}\text { Avian } \\
\text { Sewage } \\
\text { Human }\end{array}$ \\
\hline $\begin{array}{l}\text { M. bovigenital- } \\
\text { ium }\end{array}$ & PG11 & Cattle & $\begin{array}{l}M . \text { maculosum } \\
M . \text { meleagridis }\end{array}$ & $\begin{array}{l}\text { PG15 } \\
17529\end{array}$ & $\begin{array}{l}\text { Dog } \\
\text { Turkey }\end{array}$ \\
\hline $\begin{array}{l}M . \text { bovirhinis } \\
M . \text { bovis }\end{array}$ & $\begin{array}{l}\text { PG43 } \\
\text { PG45 }\end{array}$ & $\begin{array}{l}\text { Cattle } \\
\text { Cattle }\end{array}$ & M. moatsii & MK405 & $\begin{array}{c}\text { African green } \\
\text { monkey }\end{array}$ \\
\hline M. bovoculi & M165/69 & Cattle & A. modicum & PG49 & Cattle \\
\hline M. buccale & CH-20247 & Human & M. molare & $\mathrm{H} 542$ & Dog \\
\hline M. californicum & ST-6 & Cattle & A. morum & $72-043$ & Cell cultures \\
\hline $\begin{array}{l}M . \text { canadense } \\
M . \text { canis }\end{array}$ & $\begin{array}{l}275 \mathrm{C} \\
\text { PG14 }\end{array}$ & $\begin{array}{l}\text { Cattle } \\
\text { Dog }\end{array}$ & M. mycoides & PG3 & Goat \\
\hline M. capricolum & $\begin{array}{l}\text { California } \\
\text { Kid }\end{array}$ & Goat & $\begin{array}{l}M . \text { mycoides } \\
\text { subsp. my- }\end{array}$ & PG1 & Cattle \\
\hline M. caviae & G122 & Guinea pig & coides & & \\
\hline M. citelli & RG-2C & Squirrel & M. neurolyticum & Type A & Mouse \\
\hline M. columbinum & MMP1 & Pigeon & A. oculi & 19L & Goat \\
\hline M. columborale & MMP4 & Pigeon & M. opalescens & MH5408 & Dog \\
\hline M. conjunctivae & HRC581 & Sheep, goat & $M$. orale & CH-19299 & Human \\
\hline M. cynos & H831 & Dog & M. ovipneumo- & Y98 & Sheep \\
\hline M. dispar & $462 / 2$ & Cattle & niae & & \\
\hline M. edwardii & PG24 & Dog & M. pneumoniae & $\mathrm{FH}$ & Human \\
\hline A. equifetale & N93 & Horse & $M$. primatum & HRC292 & Human \\
\hline $\begin{array}{l}\text { M. equigenital- } \\
\text { ium }\end{array}$ & T37 & Horse & $\begin{array}{l}M . \text { pulmonis } \\
M . \text { putrefaciens }\end{array}$ & $\begin{array}{l}\mathrm{ASH} \\
\mathrm{KS} 1\end{array}$ & $\begin{array}{l}\text { Mouse } \\
\text { Goat }\end{array}$ \\
\hline M. equirhinis & $\mathrm{M} 432 / 72$ & Horse & $M$. salivarium & PG20 & Human \\
\hline M. fastidiosum & 4822 & Horse & M. spumans & PG13 & Dog \\
\hline M. faucium & DC333 & Human & M. sualvi & Mayfield & Pig \\
\hline M. feliminutum & Ben & Cat & & strain & \\
\hline M. felis & $\mathrm{CO}$ & Cat & & (Clone B) & \\
\hline M. fermentans & PG18 & Human & M. subdolum & TB & Horse \\
\hline M. flocculare & MS42 & Pig & M. synoviae & S & Chicken \\
\hline M. gallinarum & PG16 & Chicken & M. verecundum & 107 & Cattle \\
\hline M. gallisepticum & PG31 & Chicken & & & \\
\hline
\end{tabular}

gland). The width of the zone of growth inhibition was measured in millimeters (8).

Biochemical activity. Isolates were examined for carbohydrate metabolism; hydrolysis of aesculin, argi- nine, and urea; reduction of methylene blue, resazurin, tetrazolium, and tellurite; and phosphatase activity $(1,2,13,21,25,27)$.

Erythrocyte techniques. Hemolytic activity, adsorp-

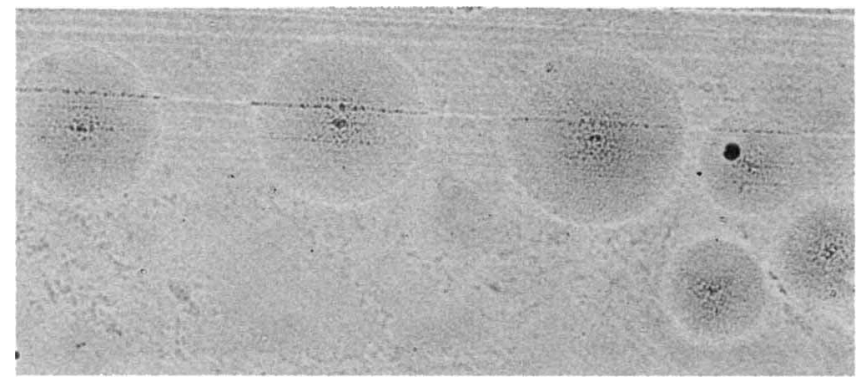

FIG. 1. Colonies of strain $\mathrm{CH}$ grown for 7 days on an agar medium. Magnification, $\times 16$. 
TABLE 2. Colonial and biochemical characteristics of Chinese hamster mycoplasmas

\begin{tabular}{l|c|c|c|c}
\hline \multirow{2}{*}{ Test } & \multicolumn{4}{|c}{ Mycoplasma strain } \\
\cline { 2 - 5 } & $\mathrm{CH}$ & $\mathrm{SH}$ & $\mathrm{LE}$ & $\mathrm{HO}$ \\
\hline $\begin{array}{l}\text { Aerobic growth (pearly } \\
\quad \text { layer) }\end{array}$ & $+(-)$ & $+(-)$ & $+(-)$ & $+(-)$ \\
Anaerobic growth (pearly & $+(-)$ & $+(-)$ & $+(-)$ & $+(-)$ \\
$\quad$ layer) & & & & \\
Growth on methylene & - & - & - & - \\
$\quad$ blue agar & & & & \\
Clearing on egg yolk agar & + & + & + & + \\
Film on egg yolk agar & + & + & + & + \\
Growth without serum & - & - & - & - \\
Aesculin hydrolysis $\left(\mathrm{O}^{2}\right)$ & - & - & - & - \\
Arginine hydrolysis & - & - & - & - \\
Urease production & - & - & - & - \\
Methylene blue reduction & + & + & + & + \\
Resazurin reduction & + & + & + & + \\
Tetrazolium reduction & + & + & + & + \\
Tellurite reduction & + & + & + & + \\
Casein digestion & - & - & - & - \\
Phosphatase production & + & + & + & + \\
\hline
\end{tabular}

$a+$, Positive; - , negative; $(-)$, pearly layer negative.

tion, and agglutination of erythrocytes was carried out with fowl, guinea pig, human, and sheep cells $(1,14)$.

Polyacrylamide gel electrophoresis. Electrophoresis was carried out as described previously by Razin and Rottem (19). Centrifuged cell suspensions were dried,
TABLE 3. Carbohydrate fermentation

\begin{tabular}{lcccc}
\hline & \multicolumn{4}{c}{ Fermentation $^{a}$ by strain: } \\
\cline { 2 - 5 } & $\mathrm{CH}$ & SH & LE & HO \\
\hline Arabinose & - & - & - & - \\
Arbutin & - & - & - & - \\
Cellobiose & - & - & - & - \\
Dulcitol & - & - & - & - \\
Fructose & + & + & + & + \\
Galactose & - & - & - & - \\
Glucose & + & + & + & + \\
Glycerol & - & - & - & - \\
Inositol & - & - & - & - \\
Lactose & - & - & - & - \\
Maltose & + & + & + & + \\
Mannitol & - & - & - & - \\
Mannose & + & + & + & + \\
Raffinose & + & + & + & \\
Rhamnose & - & - & - & - \\
Salicin & - & - & - & - \\
Sorbitol & - & - & - & - \\
Sucrose & + & + & + & + \\
Trehalose & - & - & - & - \\
Xylose & - & - & - & - \\
\hline
\end{tabular}

${ }^{a}+$, Ferments carbohydrate; - , does not ferment carbohydrate.

and $6 \mathrm{mg}$ was dissolved in $0.6 \mathrm{ml}$ of phenol-acetic acidwater $(2: 1: 0.5 ; \mathrm{vol} / \mathrm{vol} / \mathrm{vol})$. To the gels were added $0.025 \mathrm{ml}$ and $0.05 \mathrm{ml}$ of the cell sample. Electrophore-

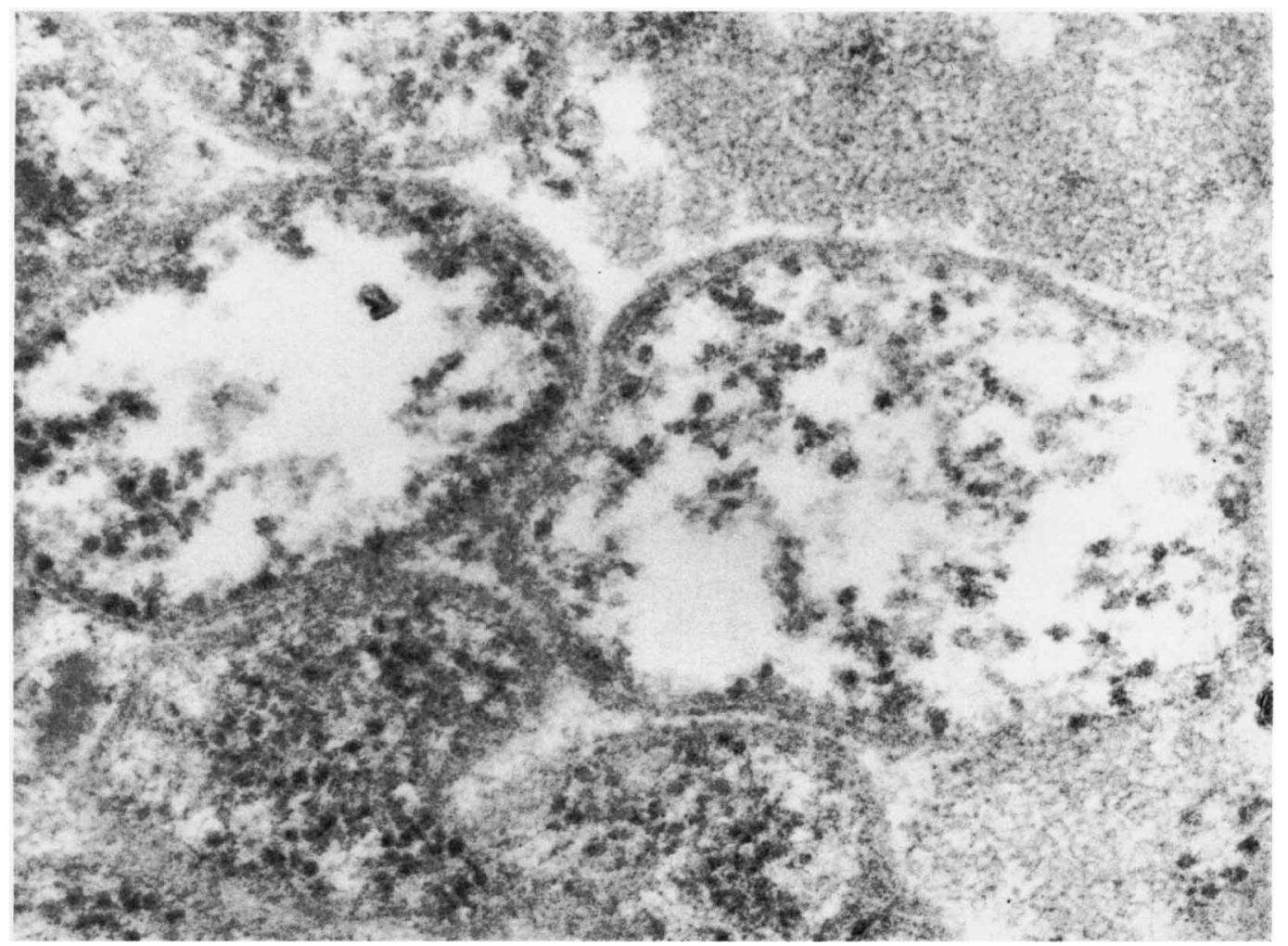

FIG. 2. Electron micrograph of Mycoplasma sp. strain CH. Magnification, $\times 40,000$. 
TABLE 4. Serological reactions

\begin{tabular}{lcccc}
\hline & \multicolumn{4}{c}{$\begin{array}{c}\text { Growth inhibition }(\mathrm{mm}) \\
\text { against: }\end{array}$} \\
\cline { 2 - 5 } Antigen & $\mathrm{CH}$ & SH & LE & HO \\
\hline CH & 6 & 6 & 6 & 6 \\
SH & 7 & 7 & 7 & 6 \\
LE & 5 & 6 & 6 & 7 \\
HO & 6 & 6 & 6 & 6 \\
\hline
\end{tabular}

sis was carried out at room temperature for $3.5 \mathrm{~h}$ at a constant current of $5 \mathrm{~mA}$ per tube, and the gels were stained with $1 \%$ naphthol blue black.

Serological studies. Antisera were prepared as described previously by Morton and Roberts (15) and Hill (9). Three methods were used: growth inhibition (3), metabolism inhibition $(11,17,18,22)$, and immunoperoxidase on colonies grown on agar (16). All tests were carried out in duplicate. The Chinese hamster mycoplasmas were reacted with antisera prepared against the species listed in Table 1. Antiserum to strain $\mathrm{CH}$ was tested with the named Mycoplasma species.

Antisera to the Chinese hamster mycoplasmas were reacted with each of the four strains to demonstrate their relationship to eash other.

\section{RESULTS AND DISCUSSION}

Colonies were visible after 2 to 3 days of incubation under both aerobic and anaerobic conditions. Although the colonies showed the "fried egg" appearance, the centers were usually very small (Fig. 1). Growth characteristics are shown in Table 2.

None of the isolates reverted to bacteria when subcultured onto medium without bacterial inhibitors. Their colonies rapidly became stained with Diene stain, indicating that these isolates were true mycoplasmas and not bacterial Lforms.

No motility was noticed under dark-field microscopy. Liquid cultures stained with Giemsa stain showed short filaments and ring forms. The organisms were typical of mycoplasmas when viewed by the electron microscope and were bounded by a membrane (Fig. 2).

Filtration of the mycoplasmas showed that of $2.5 \times 10^{6}$ organisms per $\mathrm{ml}$ in the original dilution, reduced numbers passed through the 450 -nm $\left(2.5 \times 10^{4}\right)$ and 300 -nm $\left(4 \times 10^{2}\right)$ mem-

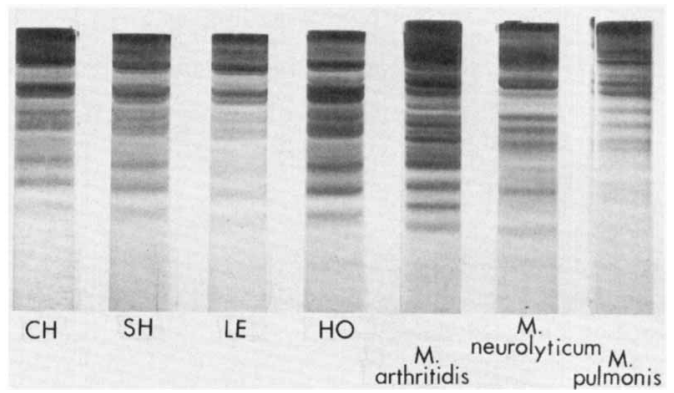

FIG. 3. Electrophoretic protein patterns.

branes, and no organisms passed through the 220-nm membrane.

The organisms were shown to require cholesterol $(1 \mu \mathrm{g} / \mathrm{ml})$ for growth. They were susceptible to digitonin and sodium polyanetholsulfonate with 8- to 9-mm- and 6- to 8-mm-zones of growth inhibition respectively.

The Chinese hamster mycoplasmas belong to the genus Mycoplasma, as they are dependent upon sterol for growth and are susceptible to digitonin and sodium polyanetholsulfonate, and because urease could not be demonstrated.

Biochemical activity is shown in Tables 2 and 3. The isolates metabolized some carbohydrates, i.e., fructose, glucose, maltose, mannose, raffinose, and sucrose. They did not hydrolyze arginine. The mycoplasmas lysed but did not adsorb erythrocytes. They agglutinated sheep erythrocytes, but not human or guinea pig erythrocytes.

The electrophoretic protein patterns are shown in Fig. 3. All four strains gave a similar pattern and were distinct from the rodent mycoplasmas.

Serological techniques showed a high level of cross-reactions among the four isolates (Tables 4 through 6). As high cross-reactions were demonstrated between the four isolates $\mathrm{CH}, \mathrm{SH}, \mathrm{LE}$, and $\mathrm{HO}$ in all of the serological tests and as the isolates have similar characteristics, they belong to the same species.

No cross-reactions were detected with any of the species in Table 1. Because the species showed no serological cross-reactions with any of the named Mycoplasma spp., it is therefore a new species.

TABLE 5. Serological reactions

\begin{tabular}{lcccr}
\hline \multirow{2}{*}{ Antigen } & \multicolumn{4}{c}{ Titer of metabolism inhibition with antiserum against: } \\
\cline { 2 - 4 } & $\mathrm{CH}$ & $\mathrm{SH}$ & $\mathrm{LE}$ & HO \\
\hline $\mathrm{CH}$ & 2,048 & 2,048 & 4,096 & 4,096 \\
SH & 4,096 & 4,096 & 4,096 & 4,096 \\
LE & 2,048 & 2,048 & 1,024 & 4,096 \\
HO & 4,096 & 8,192 & 8,192 & 4,096 \\
\hline
\end{tabular}


TABLE 6. Serological reactions

\begin{tabular}{|c|c|c|c|c|}
\hline \multirow{2}{*}{ Antigen } & \multicolumn{4}{|c|}{ Immunoperoxidase titer with antiserum against: } \\
\hline & $\mathrm{CH}$ & SH & LE & HO \\
\hline $\mathrm{CH}$ & 19,000 & 38,000 & 38,000 & 19,000 \\
\hline $\mathrm{SH}$ & 9,500 & 19,000 & 19,000 & 19,000 \\
\hline LE & 19,000 & 38,000 & 38,000 & 9,500 \\
\hline $\mathrm{HO}$ & 19,000 & 38,000 & 38,000 & 19,000 \\
\hline
\end{tabular}

It is suggested that the species be named Mycoplasma cricetuli type strain CH, NCTC 10190.

\section{ACKNOWLEDGMENTS}

I thank C. Tram, Pasteur Institute, Paris, France, for taking the electron microscope photographs and R. Brooks, MRC Laboratories, Carshalton, England, for the other photographs.

\section{LITERATURE CITED}

1. Aluotto, B. B., R. G. Wittler, C. O. Williams, and J. E. Faber. 1970. Standardized bacteriologic techniques for the characterization of Mycoplasma species. Int. J. Syst. Bacteriol. 20:35-58.

2. Barber, T. L., and J. Fabricant. 1971. Identification of Mycoplasmatales: characterization procedures. Appl. Microbiol. 21:600-605.

3. Clyde, W. A., Jr. 1964. Mycoplasma species identification based upon growth inhibition by specific antisera. J. Immunol. 92:958-965.

4. Edward, D. G. 1971. Determination of sterol requirement for Mycoplasmatales. J. Gen. Microbiol. 69:205-210.

5. Edward D. G., and W. A. Fitzgerald. 1951. Cholesterol in the growth of organisms of the pleuropneumonia group. J. Gen. Microbiol. 5:576-586.

6. Fabricant, J., and E. A. Freundt. 1967. Importance of extension and standardization of laboratory tests for the identification and classification of mycoplasma. Ann. N.Y. Acad. Sci. 143:50-58.

7. Fallon, R. J., and P. Whittlestone. 1969. Isolation, cultivation and maintenance of mycoplasmas, p. 251-252. In J. R. Norris and D. W. Robbins (ed.), Methods in microbiology, vol. 3B. Academic Press, Inc., New York.

8. Freundt, E. A., B. E. Andrews, H. Erno, M. Kunze, and F. T. Black. 1973. The sensitivity of mycoplasmatales to sodium-polyanethol sulfonate and digitonin. Zentralbl. Bakteriol. Parasitenkd. Infektionskr. Hyg. Abt. 1 Orig. Reihe A 225:104-112.

9. Hill, A. C. 1971. Mycoplasma caviae, a new species. J. Gen. Microbiol. 65:109-113.

10. Hill, A. C. 1974. Mycoplasmas of small animal hosts, p. 311-316. In J. M. Bove and J. F. Duplan (ed.), Les Mycoplasmes/Mycoplasmas. Inserm. 11-17 Septembre. Les Colloques de l'Institut National de la Santé et de la Recherche Médicale. vol. 33. Paris.

11. Hill, A. C. 1977. The metabolic inhibition test for mycoplasmas based on phosphatase production. J. Hyg. 79:391-393.

12. Klieneberger-Nobel, E. 1962. Morphology of pleuropneu- monia-like organisms, p. 23-56. In E. Klieneberger-Nobel (ed.), Pleuropneumonia-like organisms (PPLO). Mycoplasmataceae. Academic Press, Inc., New York.

13. Leach, R. H. 1976. The inhibitory effect of arginine on growth of some mycoplasmas. J. Appl. Bacteriol. 41:259 264.

14. Manchee, R. J., and D. Taylor-Robinson. 1968. Haemadsorption and haemagglutination by mycoplasmas. J. Gen. Microbiol. 50:465-478.

15. Morton, H. E., and R. J. Roberts. 1967. Production of anti-mycoplasma (PPLO) antibodies in rabbits. Proc. Soc. Exp. Biol. Med. 125:538-543.

16. Polak-Vogelzang, A., A. R. Hagenaars, and S. Nagel. 1978 Evaluation of an indirect immunoperoxidase test for identification of Acholeplasma and Mycoplasma. J. Gen. Microbiol. 106:241-249.

17. Purcell, R. H., D. Taylor-Robinson, D. C. Wong, and R. M. Chanock. 1966. A color test for the measurement of antibody to the non-acid-forming human mycoplasma species. Am. J. Epidemiol. 84:51-66.

18. Purcell, R. H., D. Taylor-Robinson, D. Wong, and R. M. Chanock. 1966. Color test for the measurement of antibody to T-strain mycoplasmas. J. Bacteriol. 92:6-12.

19. Razin, S., and S. Rottem. 1967. Identification of mycoplasma and other micro-organisms by polyacrylamide-gel electrophoresis of cell proteins. J. Bacteriol. 94:18071810.

20. Razin, S., and J. G. Tully. 1970. Cholesterol requirement of mycoplasmas. J. Bacteriol. 102:306-310.

21. Shepard, M. C., and D. R. Howard. 1970. Identification of " $T$ " mycoplasmas in primary agar cultures by means of a direct test for urease. Ann. N.Y. Acad. Sci. 174:809-819.

22. Taylor-Robinson, D., R. H. Purcell, D. C. Wong, and R. M. Chanock. 1966. A colour test for the measurement of antibody to certain mycoplasma species based upon the inhibition of acid production. J. Hyg. 64:91-104.

23. Taylor-Robinson, D., M. H. Williams, and D. D. Haig. 1968. The isolation and comparative biological and physical characteristics of T-mycoplasmas of cattle. J. Gen. Microbiol. 54:33-46

24. Timms, L. 1967. Isolation and identification of avian mycoplasmas. J. Med. Lab. Technol. 24:79-89.

25. Tully, J. G. 1965 . Biochemical, morphological and serological characterization of mycoplasma of murine origin. J. Infect. Dis. 115:171-185.

26. Tully, J. G., and S. Razin. 1969. Characteristics of a new sterol non-requiring mycoplasma. J. Bacteriol. 98:970978.

27. Williams, C. O., and R. G. Wittler. 1971. Hydrolysis of aesculin and phosphatase production by members of the order Mycoplasmatales which do not require sterol. Int. J. Syst. Bacteriol, 21:73-77. 